\title{
Service Quality Delivery of Rural Banks: Perception of Customers in Emerging Economies
}

\section{Michael Ayikwei Quarshie ${ }^{1 \bowtie}$ \\ Reginald Djimatey ${ }^{2}$ (D) \\ Ama Abakah-Anaman ${ }^{3}$}

\author{
${ }_{1,2}$ Department of Entrepreneurship and Business Sciences, University of Energy and Natural Resources, Sunyani, \\ Brong Ahafo Region, Ghana \\ 'Email:michael.quarshie@uenr.edu.gh \\ sEmail: reginald.djimatey@uenr.edu.gh \\ ${ }^{3}$ Takoradi Technical Institute, Takoradi, Western Region, Ghana \\ Email:anaman ama@yahoo.com
}

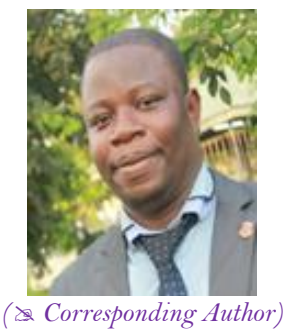

(A) Check for updates

\begin{abstract}
The aim of this study was to investigate service quality delivery of rural banks in emerging economies from the customers' perspective. This study employed descriptive design. A questionnaire designed by the researchers was used to obtain data from 382 customers, using convenience sampling technique. Data were presented and analyzed using descriptive statistics which included frequencies, percentages, means and standard deviation. The study found that customers want rural banks in Takoradi to establish more convenient branches i.e. sub branches, outlets and further extend banking hours to resolve overcrowding at the banking halls. It was therefore recommended that management of these rural banks in Takoradi, Ghana should liaise with stakeholders to establish more branches in its catchment areas to ease the frequent congestion in the banking halls.
\end{abstract}

Keywords: Service quality delivery, Rural bank, SERVQUAL, Customer satisfaction, Responsiveness, Empathy, Assurance, Reliability, Tangibility, Perception

JEL Classification: M30

\section{Introduction}

In the rural banking sector, service quality remains a very essential part of customers' experience. As a result, most rural banks consistently appraise their services to promote customer satisfaction, keeping in mind the end goal to improve consumer loyalty.

As demonstrated by Swar and Sahoo (2012), clients are satisfied when rural banks offer quality service that meets customer aspirations. Quality service rendered by banks along these lines creates a more fulfilled client. Some studies (Chandon et al., 1997; Jallat and Wood, 2005; Farayibi, 2016) have pointed out that the satisfaction of customers is highly dependent on the quality of service offered by an organization. The quality of service delivery is noted as a very influential variable in maintaining the satisfaction of customers which leads to the promotion of customer loyalty in the long run.

The banking sector has seen some various degrees of innovations in recent times. These have been as a result of new advances in technology and marketing, stiff competition, advertisement, unfavorable economic conditions, unpredictable customers and rapid changing business climate. Notably, the foregoing factors pose some challenges to these rural banks. Increased product varieties, diffusion and competition as well as highly enlightened consumers require that bank marketers solicit views on how to meet customer satisfaction through effective service quality delivery.

Because of the swift advancement in technology and stiff competition, most firms, especially banks, must provide excellent services to accomplish the dynamic banking needs of their customers. In a bid to maximize customer satisfaction, rural banks must examine the kind of service offered to customers.

Rural banking in Ghana today is transforming to warmly embrace the customer needs in their strategic orientation. Besides their dominance in the rural areas under their catchment areas, rural banks now find themselves in major cities that are within the mandated 40-kilometer radius. Universal banks are opening more mobilization centres in urban places. However, the challenge is that as rural economies undergo fundamental changes, so do the universal banks.

Banking deregulation in recent times has encouraged the evolution of new financial institutions much as the nationwide branching of existing ones (Addeah, 2001).

Larger financial institutions by virtue of their flexible policy regulations are extending their services and products from the cities into these rural places and competing with the rural banks. It is thus a common activity to witness the rural communities flooded with commercial banking and micro financing institutions (Bank of Ghana, 
2011). In order to raise funds to fulfill their mandate of meeting financial obligation of the rural communities, rural banks have to re-strategise and expand into economically viable areas.

However, unlike the universal banks that have the freedom to raise equity capital and open branches without constraints, rural banks are constrained by two main factors: they are permitted to operate within a forty-kilometer radius from their head office and equity capital is mainly sourced from their shareholders from their catchment area (Association of Rural Banks, 2002).

These characteristics place restriction on the competitiveness of rural banks in the financial sector. Many rural banks find themselves disadvantaged by the recent economic and financial changes as well as deregulations in other financial establishments. This policy restriction poses as a regulatory burden on the rural banks, making it difficult for them to compete favourably with their counterparts in the other financial institutions.

The above demands that rural banks must surely improve the quality of service offered in a bid to attract and satisfy the banking needs of their customers. Satisfied customers become royal and provide sustained revenue for the rural banks (Swar and Sahoo, 2012).

Satisfied customers also attract potential clients into rural banks. To these effects all organizations strive for customer satisfaction. High patronage of service offered by an organization largely relies upon the satisfaction that customers get from that service.

Remarkably, sales to some extent are directly linked to customer satisfaction as increase in sales requires constant improvement in the service quality, leading to continuous patronage. As a result, the SERVQUAL model which was developed by Parasuraman et al. $(1985 ; 1988)$ has been employed by many researchers globally to measure the quality of service offered by various institutions.

Parasuraman et al. (1988) conceptualized the SERVQUAL model as an instrument to measure the quality of service based on the suggestion that quality of service is the difference between a customer's expectations and perception of service delivery.

As it were, service quality assessment is conceptualized as the gap between what clients anticipate from a kind of service offered by an organization and the assessments of the performance of that particular service offered by that organization. Parasuraman et al. (1988) established, that high degrees of relationship exist between correspondence, ability, graciousness and security on one hand, and access and comprehension on the other.

They developed two dimensions of empathy and assurance to make up the five merged dimensions, specifically, tangibility, reliability, responsiveness, assurance and empathy. These measurements, therefore, served as the basis for measuring or assessing the quality of service delivery of rural banks in this study.

Though some rural banks have introduced some few programmes and policies aimed at mitigating the needs of its customers, no much scientific study has been done by the rural banks to ascertain whether or not these interventions have been able to yield the expected return.

These programmes include provision of appealing materials and equipment's, provision of convenient branches (sub branches, outlets) and operating in extended hours to all its customers without wasting much time in long queues. It is against this background that this study sought to apply the measurement to investigate service quality delivery of rural banks in an emerging economy, Ghana from the customers' perspective.

\section{Literature Review}

\subsection{The Concept of Service Offering}

Unlike tangible products, a service is an unpredictable phenomenon and many segmented definitions have surfaced (Jallat and Wood, 2005; Hirvonen, 2007). Jallat and Wood (2005) characterized a service as a concurrent process, a social interaction, a relationship and an intangible result. Zeithaml et al. (2000) noted that services can be observed as deeds, procedures and performance.

As indicated by Kotler and Keller (2006) a service is a demonstration or execution that one party can offer another that is basically elusive and does not result in the ownership of anything. Different authors have proffered various definitions relative to what service is or is not. Notwithstanding the different definitions, many believe that services are intangible, interactive, experiential and do not include the exchange of possession

\subsection{Characteristics of Service}

There are four special service characteristics that distinguish services from goods. As noted by Zeithaml et al. (2006); Zeithaml et al. (2000) and Soutar and McNeil (1996) the four fundamental attributes that separate services from goods are inseparability, intangibility, variability and perishability.

Zeithaml et al. (1990) in admission recognized intangibility, heterogeneity, perishability and inseparability as the principal attributes that makes service not the same as goods as far as how they are delivered, expended and evaluated.

\subsection{Types of Service}

Studies (Bitner, 1990; Chandon et al., 1997; Liljander and Mattsson, 2002) have indicated distinctive sorts of connections that may happen in an experience. These are face-to-face interactions, remote interactions, and phone interactions (Surprenant and Solomon, 1987; Bitner, 1990; Chandon et al., 1997; Liljander and Mattsson, 2002). It has also been suggested that the different categories of service encountered may affect the overall service assessment (Danaher and Mattsson, 1994; Liljander and Mattsson, 2002).

\subsection{Service Delivery in Banks}

Service delivery is very much associated with the kind of quality services provided to clients or customers. Bank service delivery can simply be observed as the delivery and provision of quality services rendered to customers. Banks' ability to render a good quality service to their clients would definitely be evident in their customer base as every customer would want a quality service (Farayibi, 2016). 
Obviously, one of the components that separate competitors (banks) from the others (different banks) in the Ghanaian financial sector is their quality, level and nature of service rendered. This is on the grounds that service quality delivery decides the level of clients' satisfaction and thus, the client base of any bank. The support by clients on the quality of service delivery by a given bank, presumably, is subject to the level of the fulfillment they so get from it.

Satisfaction in connection to a bank service quality delivery is the clients' assessment of the service regarding whether that service addressed his or her issues and desires (Ako-Nai, 2011). Happy and satisfied customers behave in a positive manner.

The impact of service quality delivery by banks and the satisfaction resultant by clients are getting to be recognizable. Given that contemporary clients are more enlighten and informed in recent time, Mkoma (2014) puts forward that meeting clients' desire in relations to satisfaction is progressively becoming more cumbersome.

\subsection{The Concept of Quality}

Some literature suggests that it is quite difficult to define quality (Zeithaml et al., 2006). There is no globally acknowledged definition of the term quality.

The term quality has been viewed differently by many researchers'. Quality might be characterized as a property of goods or service, or procedures in delivering these goods or services (Sahney et al., 2004) characterized quality as meeting or surpassing client desires or expectation. Some researchers contend that quality is the way clients characterize it Lovelock and Wirtz (2007) and must be characterized from client's point of view. Sahney et al. (2004) contend that customer's definition of quality product helps distinguish and build up the applicable bases and criteria for assessing quality.

A meaning of "quality" was given by Coulson-Thomas and Brown (1990) from customer's point of view. They viewed quality as: "How reliably or dependent is the product or service rendered, meets or surpasses the customer? (external and internal) expectations and needs".

Brenda and Steve (2000) support this view and postulate that the term quality alludes to a state of mind about how to conduct business, regardless of the kind of business adventure. That state of mind fixates on two things: the first being meeting or surpassing customers' wants, needs, and desires and the second is, doing it in a productive way. It does no great to deliver a phenomenal product that no one needs, similarly as it does no great to create a superb item utilizing wasteful procedures. The quality concept then refers not just product or service provided but also how it is provided.

\subsection{SERVQUAL Model}

Zeithaml et al. (2000) define service quality as “... a global judgment or attitude relating to the overall excellence or superiority of the service". They conceptualized a customer's assessment of overall quality of service by applying (Oliver, 1980) disconfirmation model, as the gap among desires and views of service assessment levels. Besides, Zeithaml et al. (2000) recommend that overall quality of service assessment could be controlled by the measurement scale, SERVQUAL which employs five generic measurements: Tangibles (the presence of physical facilities, equipment, personnel, and communications materials); Reliability (the capacity to perform the guaranteed benefit constantly and precisely); Responsiveness (the readiness to help clients and offer prompt service); Assurance (the competence of the system and its believability in giving a courteous and secure service); and Empathy (the approachability, ease of access and exertion taken to comprehend client's needs).

Parasuraman et al. (1985) from their exploratory research developed the SERVQUAL instrument and set out a theoretical framework for the measurement of quality of service. The SERVQUAL instrument has since become the most prevailing instrument for measuring quality of service. It initially comprises 10 measurements with 97 items. However, this was later reduced to 5 measurements with 22 items in 1991. The five dimensions are tangibles, reliability, responsiveness, assurance and empathy.

\subsubsection{Tangibility}

Tangibles involve the physical proof of the service. According to Zeithaml et al. (2006) tangibles in details normally show physical facilities of the service provider, the appearance of personnel, materials associated to the service (credit and debit sheets, cheque books etc.), decorations and business hours, the tools and equipment used to provide the service. Tangibles are usually used by firms to express image and signal quality.

\subsubsection{Reliability}

According to Zeithaml et al. (2006) reliability is "the ability to perform the promised service dependably and accurately" or "delivering on its promises ". Does the firm deliver the service comfortable the first time? Does the firm respects it promises? These are a portion of the inquiries which should be answered by providers of service if they are to accomplish unwavering quality.

This measurement of quality service as indicated by Parasuraman et al. (1985) is the means by which the providers of service can give service to a client as promised, tried and true in dealing with clients' service issues, performs service right at the first instance, give service at guaranteed time and keep clients always informed about when service will be performed or available.

\subsubsection{Assurance}

Assurance involves the knowledge and courtesy of employees and their capacity to pass on trust and certainty. It likewise incorporates skill, obligingness, believability and security. In the view of Saad Andaleeb and Conway (2006) assurance may not be so vital with respect to different industries where the risk is higher and the result of utilizing the service is questionable.

For example, in the medical and healthcare industry, assurance is an imperative measurement that clients utilize as criteria in evaluating a health center or a specialist for a task. The trust and ultimate confidence might be visible in an employee who connects the client to the organization (Zeithaml et al., 2006). 


\subsubsection{Responsiveness}

Responsiveness concerns the ability or preparation of employees to offer service (Parasuraman et al., 1985). Responsiveness is concerned with managing the client's inquiries and concerns and immediately attending to that concerns or providing solution to this issues.

A firm is known to be responsive when it conveys to its clients to what extent it would take to find solutions or have their issues managed. To be effective, organizations need to take a look at responsiveness from the view point of the client as opposed to the organization's point of view (Zeithaml et al., 2006).

\subsubsection{Empathy}

Empathy involves minding and arrangement of individualized regard for clients by employees of the firm (Zeithaml et al., 2006).

In this respect, the client feels exceptional and extraordinary. While trying to create empathy, employees of the firm should try to know the names of their clients, their inclinations and needs and find a way to fulfill them. Small scale organizations through the customized services to customers are in a superior position to accomplish empathy than large organizations.

\section{Research Methodology}

This study adopted a descriptive survey design. This descriptive research is designed to describe the existing situations and the features of rural banks in Takoradi. The researchers sought to answer the questions who, what, when, where and how (Zikmund, 2003).

In this study, the researchers applied a survey technique by distributing questionnaires to gain feedback from respondents and to gain understanding about perceive customer service delivery at the rural banks. According to Zikmund (1994) a survey technique can gather data or information from people by using a questionnaire. In that regard this survey uses questionnaire to collect data.

Study population is a group of people who have the information that researchers seek and from which conclusions can be acquired (Malhotra and Birks, 2007). In this case, the study population was 8,513 customers from the rural banks as follows: Ahantaman Rural Bank Ltd, Lower Pra Rural Bank Ltd, Arb Apex Bank Ltd, Mansoman Rural Bank Ltd and Lower Amenfi Rural Bank Ltd Amanfrom in Takoradi. From the total population, the sample size was 382 respondents. This was determined using the Sloven's formula; which states as follows: $\mathrm{n}=$ $\frac{N}{1+N(e) 2}$ where $\mathrm{n}=$ sample size, $\mathrm{N}=$ accessible population and $\mathrm{e}=$ level of significance at 0.05.

The study employed non-probability sampling technique, specifically, convenience sampling technique was used to obtain data because it is generally believed to be fast, easy, inexpensive, and the customers are reachable for the study. The sample comprises customers who were demanding service and were present at the banking hall during the data collection period.

Researchers employ convenience sampling in light of the fact that it additionally has other research advantages apart from ease of availability and time saving. Convenience sampling is generally utilized on the grounds that it enables the researchers to get essential information and trends relative to the study without the inconveniences of utilizing a randomized sample. The main instrument employed for the data collection was a structured closedended questionnaire.

The questionnaire was designed to provide specific responses aimed at addressing the research question. Respondents were given a questionnaire to fill. Likert scales were used in measuring the variables of interest that have to do with respondents' level of perceived banking service quality delivery. Fifteen questions on quality service delivery were administered to the respondents on which the analysis was based. Respondents were expected to tick the chosen item that corresponds to a given mark in Likert scale starting from $1=$ least agree to $4=$ highest agree. There are some reasons behind the selection of this method. First, it allows large quantum of information to be solicited at a relatively low cost. Second, more accurate and precise responses are obtained because researchers' bias can be avoided.

In order to reduce the chances of getting a wrong answer, attention was paid to the reliability and validity of the instrument used. Some steps were taken into consideration to ensure the validity and reliability of the study: Data were obtained from the reliable sources.

Which means that a respondent must be a customer of the bank under research; questionnaire was made based on literature review; questionnaire was pre-tested by experienced persons to ensure it measured what it was supposed to; data were obtained through a short period of time. Results from the pre-test showed Cronbach's Alpha of 0.78 in line with Pallant (2007) suggestions. To ensure strict compliance with ethical standards of research, written permission was duly sought from the respective rural banks, which was duly granted before data were collected. The researchers introduced a clause in the introductory paragraph of the questionnaire assuring respondents of anonymity and confidentiality. In addition, the time required for filling the questionnaire was mutually agreed between the respondents and the researchers.

\section{Results and Conclusion}

\subsection{Respondent's Background Information}

In this study, respondents' background information was described as regards of sex, age range, highest education level, experience with the bank and type of account. Respondents were to state their characteristics for the purposes of classification and comparison. The study employed a closed ended questionnaire to categorize respondent's background information and responses were analyzed using frequencies and percentage distributions as shown in Table 1. The results indicate that males were the majority respondents as represented by 61.5 per cent while females were in the minority as represented by 38.5 per cent. This finding shows that the greater number of rural banking populace in Takoradi is dominated by male customers. 
About 32.5 per cent of the respondents indicated that their ages fell within the range 26-35 years. This was followed by 23.8 per cent whose ages range between 36-45 years. About 13.9 per cent of the respondents affirmed the age range of $18-25$ years.

Cumulatively, 29.9 per cent of the respondents indicated a range of 46 years and above. The finding reveals that most of customers of the rural banks in Takoradi are youthful, thus between 18-45 years. Concerning the highest educational levels of respondents, the findings show that 27.2 per cent have senior high school certificate. Approximately 29.1 per cent indicated that their highest educational level was junior high school education. About 12.3 per cent and 11.3 per cent of the respondents indicated that they have Higher National Diploma and Bachelor's Degree respectively.

The background information further presents respondents experience in terms of the number of years they have been transacting business with the rural bank. The figure shows that 37.2 per cent of the respondents had banked between 1-5 years.

This was followed by 34.0 per cent of the respondents whose bank experience spans 10 years and above. Nineteen per cent had banked between 6-10 years. This indicates that the majority of the respondents have some knowledge and experience about the rural banks since they have been customers for these respective banks for relatively longer period of time.

With regard to the type of accounts held, 45.8 per cent of the respondents hold savings account, 24.3 per cent hold salary account, 15.7 per cent hold current account and the remaining 14.2 per cent hold loan account. The findings show that most customers prefer savings account with the rural banks in Takoradi to other forms of accounts.

Table-1. Description of Respondents' Background Information

\begin{tabular}{|c|c|c|}
\hline Background information & Frequency & Per cent \\
\hline \multicolumn{3}{|l|}{ Sex } \\
\hline Male & 235 & 61.5 \\
\hline Female & 147 & 38.5 \\
\hline Total & 382 & 100 \\
\hline \multicolumn{3}{|l|}{ Age range (years) } \\
\hline $18-25$ & 53 & 13.9 \\
\hline $26-35$ & 124 & 32.5 \\
\hline $36-45$ & 91 & 23.8 \\
\hline $46-55$ & 69 & 18.0 \\
\hline 56 and above & 45 & 11.8 \\
\hline Total & 382 & 100.0 \\
\hline \multicolumn{3}{|l|}{ Highest Education Level } \\
\hline Middle School & 59 & 15.4 \\
\hline JHS & 111 & 29.1 \\
\hline SHS & 104 & 27.2 \\
\hline Diploma & 6 & 1.6 \\
\hline HND & 47 & 12.3 \\
\hline First Degree & 43 & 11.3 \\
\hline Postgraduate & 12 & 3.1 \\
\hline Total & 382 & 100.0 \\
\hline \multicolumn{3}{|c|}{ Experience with the Bank (years) } \\
\hline Below 1 year & 36 & 9.4 \\
\hline $1-5$ & 142 & 37.2 \\
\hline $6-10$ & 74 & 19.4 \\
\hline Above 11 & 130 & 34.0 \\
\hline Total & 382 & 100.0 \\
\hline \multicolumn{3}{|l|}{ Type of Account } \\
\hline Current & 60 & 15.7 \\
\hline Savings & 175 & 45.8 \\
\hline Loan & 54 & 14.2 \\
\hline Salary & 93 & 24.3 \\
\hline Total & 382 & 100.0 \\
\hline
\end{tabular}

\subsection{Level of Perceived Service Quality Delivery}

The objective of this study was set to determine the level of perceived service quality delivery in rural banks in Takoradi, Western Region, Ghana. Service quality delivery was measured using fifteen quantitative questions. Respondents were required to indicate the extent to which they agree with each statement by indicating the number that best describes their perception.

All the fifteen items on service quality delivery were Likert scaled using four points ranging between $1=$ least agreement and $4=$ highest agreement. The responses were analyzed and described using means and standard deviations as summarized in Table 2 .

In relation to the tangibility dimension, the results revealed that most of the respondents expressed high agreement on whether employees at the rural bank are neat in appearance (mean $=2.86$, std $=1.19$ ). The results obtained further showed that the rural banks in Takoradi have modern looking equipment (computers, fast ICT facilities etc.) $($ mean $=2.67$, std $=1.29)$. The respondents, however, expressed low agreement with regard to 
whether materials and equipment associated with the service by the bank (such as ATM, pamphlet or bank statements) are visually appealing and easy to understand at the bank (mean $=1.81$, std $=1.02)$.

With respect to the reliability dimension, the results showed that most respondents expressed high level of agreement on whether customers feel secure in transacting business with the rural banks (mean $=2.95$, std $=1.28$ ). Another issue on whether or not when the rural bank fulfils their promises when they promise to do something by a certain time, attracted high levels of agreement on the part of the respondents (mean $=2.71$, std $=1.23)$. Most respondents highly agreed that the rural banks perform services right at the very first instance $($ mean $=2.64, \mathrm{std}=$ $1.31)$.

On the responsiveness dimension of service quality delivery, the findings revealed that most respondents expressed very high agreement on the item that employees of the rural banks are always willing to help customers when they face any kind of challenge $($ mean $=3.57$, std $=0.75)$. The results further showed that respondents expressed very high agreement on the issue that employees keep customers informed as to when a service would be performed $($ mean $=3.53$, std $=0.69$ ).

Respondents again expressed very high levels of agreement on the issue that employees at the rural bank give customers immediate service when customers visit the rural bank (mean $=3.39$, std $=0.94)$.

In relation on the assurance dimension of service quality delivery, the findings reveal that employees at the rural bank make customers feel safe in their transactions (account maintenance, cash transfer, cash withdrawal and deposit) $($ mean $=3.05$, std $=1.16)$.

The respondents highly agreed that most employees of the rural bank have strong knowledge and therefore are in the position to answer customers' questions about their offers and operations ( Respondents highly agreed that at any material time employees at the bank are consistently courteous to customers $($ mean $=2.76$, $\mathrm{std}=1.33)$.

Table-2. Description of the Level of Service Quality Delivery

\begin{tabular}{|c|c|c|c|}
\hline & Mean & Std. Dev. & Interpretation \\
\hline \multicolumn{4}{|l|}{ Tangibility } \\
\hline Employees at the bank are neat in appearance & 2.86 & 1.19 & High \\
\hline $\begin{array}{l}\text { The rural bank has modern looking equipment (computers, fast } \\
\text { ICT facilities etc.) }\end{array}$ & 2.67 & 1.29 & High \\
\hline $\begin{array}{l}\text { Materials and equipment associated with the service (such as ATM } \\
\text { Machines, pamphlet or bank statements) are visually appealing and } \\
\text { easy to understand at the bank }\end{array}$ & 1.81 & 1.02 & Low \\
\hline Sub-total & 2.45 & & Low \\
\hline \multicolumn{4}{|l|}{ Reliability } \\
\hline Customer feels secure in transacting business with the bank & 2.95 & 1.28 & High \\
\hline $\begin{array}{l}\text { When the bank promises to do something by a certain time, they } \\
\text { do it. }\end{array}$ & 2.71 & 1.23 & High \\
\hline The bank performs services right the first time. & 2.64 & 1.31 & High \\
\hline Sub-total & 2.77 & & High \\
\hline \multicolumn{4}{|l|}{ Responsiveness } \\
\hline $\begin{array}{l}\text { Employees of the bank are always willing to help customers when } \\
\text { they face any kind of challenge. }\end{array}$ & 3.57 & 0.75 & Very high \\
\hline $\begin{array}{l}\text { Employees keep customers informed as to when service will be } \\
\text { performed. }\end{array}$ & 3.53 & 0.69 & Very high \\
\hline $\begin{array}{l}\text { Employees at the bank give customers immediate service when } \\
\text { they go to the bank. }\end{array}$ & 3.39 & 0.94 & Very high \\
\hline Sub-total & 3.49 & & Very high \\
\hline \multicolumn{4}{|l|}{ Assurance } \\
\hline $\begin{array}{l}\text { Employees at the bank make customers feel safe in their } \\
\text { transactions (account maintenance, cash transfer, cash withdrawal } \\
\text { and deposit) }\end{array}$ & 3.05 & 1.16 & High \\
\hline $\begin{array}{l}\text { Most employees of the bank have strong knowledge to answer } \\
\text { customers' questions about their offers and operations }\end{array}$ & 2.81 & 1.27 & High \\
\hline $\begin{array}{l}\text { At any material time employees at the bank are consistently } \\
\text { courteous to customers. }\end{array}$ & 2.76 & 1.33 & High \\
\hline Sub-total & 2.87 & & High \\
\hline \multicolumn{4}{|l|}{ Empathy } \\
\hline $\begin{array}{l}\text { Whenever customers request for service, employees at the bank } \\
\text { give customer full attention }\end{array}$ & 2.95 & 1.30 & High \\
\hline $\begin{array}{l}\text { The bank always informs customers about new and attractive } \\
\text { schemes and always suggests to them to take correct decisions }\end{array}$ & 2.88 & 1.12 & High \\
\hline $\begin{array}{l}\text { The bank has convenient branches (sub branches, outlets) and } \\
\text { operates in extended hours to all its customers without spending } \\
\text { much time on queues }\end{array}$ & 2.34 & 1.26 & Low \\
\hline Sub-total & 2.72 & & High \\
\hline Overall total & 2.86 & & High \\
\hline
\end{tabular}

\section{Source: Primary Data, 2018}

Key: Mean range Interpretation on the level of service quality delivery

3.26 - 4.00 - Very high level; $2.51-3.25$ - High level; 1.76-2.50 - Low level; $1.00-1.75$ - Very low level 
The results on the empathy dimension of service quality delivery revealed that most respondents highly affirmed that whenever customers request for service, employees at the rural bank give customer full attention $($ mean $=2.95$, std $=1.30)$.

The findings further showed that respondents highly agreed that the rural banks always inform customers about new and attractive schemes and thus suggest to customers these new available offers to enable the customers make informed decisions $($ mean $=2.88$, std $=1.12$ ). Respondents expressed low level of agreement relative to whether the banks have convenient branches (sub branches, outlets) and operate extended hours to its customers $($ mean $=2.34$, std $=1.26)$.

\section{Conclusion}

The results revealed that service quality delivery in rural banks at Takoradi, Western Region, Ghana exists at different levels. For instance, the findings portray only one dimension with the highest (very high) level of service quality delivery; responsiveness at (mean=3.49); and which is equivalent to very high levels of agreement on the Likert scale.

Secondly, service quality delivery which corresponds with high levels of agreement on the Likert scale were assurance, reliability and empathy at (mean=2.87, 2.77 and 2.72) respectively. However, the results also showed a low level of service quality delivery relative to tangibility with a mean (means $=2.45$ ) which is equivalent to low agreement on the Likert scale. This study, therefore, documents that responsiveness to service quality delivery of rural banks in Takoradi, Ghana, is the most dominant dimension in the catchment area. The least service quality delivery dimension is, however, tangibility.

\section{Recommendations}

It is recommended that management of the rural banks in Takoradi, Western Region should liaise with stakeholders to put up more branches in their catchment areas to ease the congestion at the current banking halls. Management of the rural banks should also incorporate innovations and new technologies in the dissemination or advancement of information or alerts to customers on regular basis.

Management of the rural banks in consultation with its stakeholders should install a user friendly equipment i.e. ATMs which are visually appealing to take care of all clients both educated and illiterate. Lastly, the rural banks should continue to organize regular in-service training for their staff to equip them with new trends in customer services.

\section{References}

Addeah, K., 2001. The legal and regulatory framework of micro and rural finance institutions in Ghana. A Paper Presented at the Rural Financial Services Project Launch Workshop, Agona-Swedru, Ghana.

Ako-Nai, E.A., 2011. Effect of customer service on customer satisfaction: A case study of fidelity Bank, Adum, Kumasi. Unpublished Master's Thesis, Institute of Distance Learning, Kwame Nkrumah University of Science and Technology, Kumasi.

Association of Rural Banks, 2002. Annual Reports, Unpublished Reports on file at the Association of Rural Banks, Accra.

Bank of Ghana, 2011. Economic and financial review. Accra: Bank of Ghana.

Bitner, M.J., 1990. Evaluating service encounters: The effects of physical surroundings and employee responses. The Journal of Marketing, 54(2): 69-82. Available at: https://doi.org/10.2307/1251871.

Brenda, O.M. and B. Steve, 2000. Student perceptions of service quality in a UK university business and management faculty. Quality Assurance in Education, 8(2): 85-95. Available at: https://doi.org/10.1108/09684880010325600.

Chandon, J.-L., P.-Y. Leo and J. Philippe, 1997. Service encounter dimensions-a dyadic perspective: Measuring the dimensions of service encounters as perceived by customers and personnel. International Journal of Service Industry Management, 8(1): 65-86. Available at: https://doi.org/10.1108/09564239710161088

Coulson-Thomas, C. and R. Brown, 1990. Beyond quality: Managing the relationship with the customer. London: British Institute of Management.

Danaher, P.J. and J. Mattsson, 1994. Cumulative encounter satisfaction in the hotel conference process. International Journal of Service Industry Management, 5(4): 69-80. Available at: https://doi.org/10.1 108/09564239410068715.

Farayibi, A.O., 2016. Service delivery and customer satisfaction in Nigerian banks (MPRA Paper No. 73612). Ibadan, Nigeria: College of Allied Research and Economic Development.

Hirvonen, T., 2007. Studying in an international degree programme: From expectations to reality. Jyvaskyla: Jyvaskyla University of Applied Sciences Press.

Jallat, F. and E. Wood, 2005. Exploring “deep” and “wide” stakeholder relations in service activity. European Journal of Mark eting, 39(9/10): 1013-1024. Available at: https://doi.org/10.1108/03090560510610699.

Kotler, P. and K.L. Keller, 2006. Marketing management. 12th Edn., New York: Person Prentice Hall.

Liljander, V. and J. Mattsson, 2002. Impact of customer preconsumption mood on the evaluation of employee behavior in service encounters. Psychology \& Marketing, 19(10): 837-860. Available at: https://doi.org/10.1002/mar.10040.

Lovelock, C. and J. Wirtz, 2007. Services marketing: People, technology, strategy. 6th Edn., New Jersey: Pearson Prentice Hall.

Malhotra, N. and D. Birks, 2007. Marketing research: An applied approach. Pearson Education Ltd, Essex.

Mkoma, H., 2014. Analysis of customers' satisfaction with banking services: A case of standard chartered bank. Unpublished Master's Thesis, Department of Business Administration and Post Graduate Studies, The Open University of Tanzania.

Oliver, R.L., 1980. A cognitive model of the antecedents and consequences of satisfaction decisions. Journal of Marketing Research, $17(4)$ : 460-469. Available at: https://doi.org/10.2307/3150499.

Pallant, J., 2007. SPSS survival manual: A step by step guide to data analysis using SPSS version 15. New York: McGraw-Hill.

Parasuraman, A., V.A. Zeithaml and L.L. Berry, 1985. A conceptual model of service quality and its implications for future research. The Journal of Marketing, 49(4): 41-50. Available at: https://doi.org/10.2307/1251430.

Parasuraman, A., V.A. Zeithaml and L.L. Berry, 1988. Servqual: A multiple-item scale for measuring consumer perc. Journal of Retailing, 64(1): 12-40.

Saad Andaleeb, S. and C. Conway, 2006. Customer satisfaction in the restaurant industry: An examination of the transaction-specific model. Journal of Services Marketing, 20(1): 3-11. Available at: https://doi.org/10.1108/08876040610646536.

Sahney, S., D. Banwet and S. Karunes, 2004. A SERVQUAL and QFD approach to total quality education: A student perspective. International Journal of Productivity and Performance Management, 53(2): 143-166. Available at: https://doi.org/10.1108/17410400410515043.

Soutar, G. and M. McNeil, 1996. Measuring service quality in a tertiary institution. Journal of Educational Administration, 34(1): 72-82. Available at: https://doi.org/10.1108/09578239610107174.

Surprenant, C.F. and R.M. Solomon, 1987. Predictability and personalization in the service encounter. Journal of Marketing, 5 1(2): $86-96$. Available at: https://doi.org/10.2307/1251131.

Swar, B.N. and P.K. Sahoo, 2012. Public, private, and foreign banks. Journal of Indian Management, 9(3): 43-51. 
Zeithaml, V.A., M.J. Bitner and D.D. Gremler, 2006. Services marketing: Integrating customer focus across the firm. 4th Edn., New York, USA: McGraw-Hill.

Zeithaml, V.A., A. Parasuraman and L.L. Berry, 1990. Delivering quality service-balancing customer perceptions and expectations. New York: The Free Press.

Zeithaml, V.A., A. Parasuraman and A. Malhotra, 2000. A conceptual framework for understanding e-service quality: Implications for future research and managerial practice (Working Paper Series Report No. 00-115). London, United Kingdom: Marketing Science Institute.

Zikmund, W.G., 1994. Business research methods. 4th Edn., Orlando: The Dryden Press.

Zikmund, W.G., 2003. Business research method. 7th Edn., India: Cengage Learning. Citation | Michael Ayikwei Quarshie; Reginald Djimatey; Ama
Abakah-Anaman (2018). Service Quality Delivery of Rural Banks: Perception of Customers in Emerging Economies. Asian Business Research Journal, 3: 33-40.

History:

Received: 31 July 2018

Revised: 4 September 2018

Accepted: 9 October 2018

Published: 15 November 2018

Published: 15 November 2018
Licensed: This work is licensed under a Creative Commons

Licensed: This work is licen
Attribution 3.0 License (cc) Er

Publisher: Eastern Centre of Science and Education
Acknowledgement: All authors contributed to the conception and design of the study.

Funding: This study received no specific financial support.

Competing Interests: The authors declare that they have no conflict of interests.

Transparency: The authors confirm that the manuscript is an honest, accurate, and transparent account of the study was reported; that no vital features of the study have been omitted; and that any discrepancies from the features of the study have been omitted
study as planned have been explained.

Ethical: This study follows all ethical practices during writing.
Ethe alaned

Eastern Centre of Science and Education is not responsible or answerable for any loss, damage or liability, etc. caused in relation to/arising out of the use of the content. Any queries should be directed to the corresponding author of the article. 